\title{
Revision of Angursa (Arthrotardigrada: Styraconyxidae) with the description of a new species from Japan
}

\author{
Shinta FUJIMOTO ${ }^{1 *}$ \& Jesper Guldberg HANSEN ${ }^{2}$ \\ ${ }^{1}$ Research Center for Marine Biology, Graduate School of Life Sciences, Tohoku University, \\ 9 Sakamoto, Aomori, Aomori 039-3501, Japan. \\ ${ }^{2}$ Section of Biosystematics, Zoological Museum, Natural History Museum of Denmark, \\ University of Copenhagen, Universitetsparken 15, DK-2100 Copenhagen Ø, Denmark. \\ *Corresponding author: shinta.f@water-bears.com \\ ${ }^{2}$ E-mail: jesperguldberg@gmail.com \\ ${ }^{1}$ urn:1sid:zoobank.org:author:E030A1DD-9E91-48D9-93DD-D98F0BDFC87A
${ }^{2}$ urn:1sid:zoobank.org:author:3A2D97D6-689E-4E5E-9B57-1F5523B50F2B
}

Abstract. We re-examined the type material of five of the seven described species of the marine tardigrade genus Angursa Pollock, 1979, namely, A. abyssalis Renaud-Mornant, 1981, A. bicuspis Pollock, 1979 (type species), A. capsula Bussau, 1992, A. lanceolata Renaud-Mornant, 1981, and A. lingua Bussau, 1992. In addition, we describe A. seisuimaruae sp. nov. from the Sea of Kumano, Japan. Based on new data obtained, we amend the diagnosis of this genus, provide a taxonomic key to species, and discuss their geographical distributions.

Keywords. Beach, biogeography, deep-sea, meiobenthos, Tardigrada.

Fujimoto S. \& Hansen J.G. 2019. Revision of Angursa (Arthrotardigrada: Styraconyxidae) with the description of a new species from Japan. European Journal of Taxonomy 510: 1-19. https://doi.org/10.5852/ejt.2019.510

\section{Introduction}

The marine tardigrade genus Angursa Pollock, 1979 was originally erected for A. bicuspis Pollock, 1979, an unarmoured, slender tardigrade possessing claws with two divergent points on its digits (Pollock 1979). The description of this type species was based on a specimen collected from a beach in Massachusetts, USA (type material) and an additional specimen collected from a $400 \mathrm{~m}$ deep site off North Carolina, USA (Pollock 1979). Subsequently, Renaud-Mornant (1981) described A. bicuspis abyssalis Renaud-Mornant, 1981 and A. lanceolata Renaud-Mornant, 1981. Angursa b. abyssalis was described based on a specimen from a $2063 \mathrm{~m}$ deep site off Angola, Africa (type material), as well as on additional specimens from a $2205 \mathrm{~m}$ deep site in the North Atlantic, and from a $460 \mathrm{~m}$ deep site in the Mediterranean Sea (Renaud-Mornant 1981). Angursa lanceolata was described based on specimens collected from a $2944 \mathrm{~m}$ deep site (type material) and a $2800 \mathrm{~m}$ deep site off Namibia, Africa (RenaudMornant 1981). This second report of the genus by Renaud-Mornant (1981) mentioned the presence 
of the median cirrus, leg IV sensory organs, peduncles and proximal pads of the internal digits, which were missing in the description of the type species (Pollock 1979). The finding of another subspecies, A. bicuspis clavifera Noda, 1985 from a beach in Japan, further enriched the understanding of the genus by reporting the presence of the secondary and tertiary clavae, seminal receptacles, and leg II and III sensory organs (Noda 1985). The three subspecies of A. bicuspis (A. b. bicuspis, A. b. abyssalis, and A. b. clavifera) were elevated to species when two new species, A. capsula Bussau, 1992 and A. lingua Bussau, 1992, were described from 4140-4170 m deep sites at the manganese nodule area off Peru, South America (Bussau 1992). However, Villora-Moreno (1998) treated A. abyssalis as a junior synonym of $A$. bicuspis when he discussed the morphology of A. antarctica Villora-Moreno, 1998 which was collected from $352 \mathrm{~m}$ (type material) and $416 \mathrm{~m}$ deep sites off the South Shetland Islands, Antarctica (for coordinates, see stations L15 and L16 of Sàiz-Salinas et al. (1997)). This inconsistency in the taxonomic status of $A$. abyssalis is due to the scanty original description of the type species (Pollock 1979), which was referred to as inadequate for comparison with its congeners by Villora-Moreno (1998). To eliminate the fundamental cause of this problem and to provide a reliable platform for studying this genus, we reexamined the type material and some additional material used in the descriptions of species of Angursa except for $A$. clavifera and $A$. antarctica. We also describe a new species from Japan.

\section{Material and methods}

The type material examined in this study is deposited in the National Museum of Natural History of the Smithsonian Institute (NMNH; previous acronym: USNM, United States National Museum) (A. bicuspis), the Muséum national d'Histoire naturelle, Paris (MNHN) (A. abyssalis and A. lanceolata), the Senckenberg Natural History Museum, Frankfurt/Main, Germany (SMF) (A. lingua and A. capsula), and the Zoological Collection of Kyoto University (KUZ) (A. seisuimaruae sp. nov.). These specimens were examined using a differential interference contrast microscope Olympus BX51 or BX53.

Angursa seisuimaruae sp. nov. was extracted from a sediment sample dredged in the Sea of Kumano, Japan $\left(33^{\circ} 59.5^{\prime} \mathrm{N}, 136^{\circ} 56.7^{\prime} \mathrm{E}\right.$ to $33^{\circ} 59.7^{\prime} \mathrm{N}, 136^{\circ} 56.7^{\prime} \mathrm{E}$; depth range $768-796 \mathrm{~m}$; distance $\left.370 \mathrm{~m}\right)$ on 10 Nov. 2017 during the T/V Seisuimaru's research cruise No. 1722 (Kimura et al. 2018). The sample between mesh sizes $30-450 \mu \mathrm{m}$ was rinsed with freshwater to give the meiofauna an osmotic shock (Kristensen 1983). The meiofauna was further concentrated by the floatation method using Ludox ${ }^{\circledR}$ HS40 colloidal silica (Sigma-Aldrich Co., St. Louis) (e.g., Giere 2009). Specimens of the new species used in this study were fixed in $4 \%$ buffered formaldehyde. They were observed in distilled water and then mounted in glycerol for permanent slides.

Morphometric values were obtained to the nearest micrometre using Adobe Illustrator CS6. Figures were prepared using Adobe Photoshop CS6, Adobe Illustrator CS6, and GMT version 5.1.1 (Wessel et al. 2013).
Abbreviations
an $=$ anus
ap $=$ anal papilla
$\mathrm{cE}=$ cirrus $\mathrm{E}$
$\mathrm{ec}=$ external cirrus
go $=$ female gonopore
ic $=$ internal cirrus
lc $=$ lateral cirrus
$\mathrm{mc}=$ median cirrus
$\mathrm{pb}=$ pharyngeal bulb
$\mathrm{pc}=$ primary clava 


$$
\begin{aligned}
\mathrm{pe} & =\text { peduncle } \\
\mathrm{pp} & =\text { proximal pad } \\
\mathrm{sc} & =\text { secondary clava } \\
\mathrm{se}_{\mathrm{I}} & =\text { leg I sensory organ } \\
\mathrm{se}_{\mathrm{IV}} & =\text { leg IV sensory organ } \\
\mathrm{sr} & =\text { seminal receptacle } \\
\mathrm{tc} & =\text { tertiary clava }
\end{aligned}
$$

\title{
Results
}

\author{
Phylum Tardigrada Doyère, 1840 \\ Class Heterotardigrada Marcus, 1927 \\ Order Arthrotardigrada Marcus, 1927
}

Family Styraconyxidae Kristensen \& Renaud-Mornant, 1983 (emended by Fujimoto et al. 2017)

Genus Angursa Pollock, 1979

\section{Emended diagnosis}

Styraconyxidae with slender body; median cirrus present; papillate primary clavae; flat secondary and tertiary clavae; leg I sensory organs present; legs II and III sensory organs occasionally present; leg IV sensory organs papillate; cirri E near caudal margin of body; each digit terminates in claw with two divergent points; peduncles present at base of external digits; seminal receptacles present; terminal positioned anus occasionally with anal papillae.

Angursa bicuspis Pollock, 1979

Fig. 1

\section{Emended diagnosis}

Angursa with presence of median cirrus uncertain; primary clavae longer than lateral cirri; pedestals of primary clavae and lateral cirri absent; morphology of secondary and tertiary clavae unknown; simple, tapering cirri E present; leg I sensory organs present; presence of legs II and III sensory organs uncertain; leg IV sensory organs each as papilla with short, apical spine; robust anal papillae present; presence of seminal receptacles uncertain; presence of proximal pads of internal digits uncertain.

\section{Material examined}

\section{Holotype}

UNITED STATES OF AMERICA • 1 adult; Massachusetts, Buzzard Bay side of Penzance Point, Woods Hole; 41³1'41" N, 7040’41" W; 9 Jul. 1968; Hummon \& Pollock leg.; USNM W 50900.

\section{Remarks}

Angursa bicuspis was described based on the holotype and an additional specimen (Pollock 1979). However, their conspecificity has been doubted by Kaczmarek et al. (2015) owing to the fact that the two specimens were collected from two different environments of distant localities and that they showed morphological differences (Pollock 1979). As there is no positive evidence to regard the two specimens as conspecific, we support the opinion of Kaczmarek et al. (2015) and consider it as sufficient to base our attempt to re-diagnose $A$. bicuspis on only the holotype.

The holotype is in bad condition. However, our observation confirmed that of Pollock (1979) in the overall body shape (Fig. 1A) and the presence of the internal cirri (Fig. 1B), the external cirri (which is 
$8 \mu \mathrm{m}$, not $5.5 \mu \mathrm{m}$ as reported by Pollock 1979) (Fig. 1B), the lateral cirri, the primary clavae (Fig. 1B), the leg I sensory organs, the cirri E, the characteristic claws, and the two papillae posterior to the anus (Fig. 1C). Pollock (1979) considered the latter structure as not useful for distinguishing species referring to the variability of the caudal projection of Batillipes Richters, 1909 and the fact that it was not observed in the additional specimen. Villora-Moreno (1998) supported this view, but Noda (1985) and Bussau (1992) used this structure to distinguish this species from its congeners (reason not explained). We agree with Noda (1985) and Bussau (1992) for the following two reasons. Firstly, we consider that this character is not homologous to the caudal projection of Batillipes as Pollock (1979) suggested, but a developed form of the cuticular fold that closes the anus, homologous to the "two weak protuberances" of A. antarctica described by Villora-Moreno (1998). Secondly, as discussed in the previous paragraph, this character's presence/absence in the two specimens of Pollock (1979) is likely an interspecific variation. Thus, $A$. bicuspis can be easily distinguished from its congeners by the presence of the well-developed anal papillae (Renaud-Mornant 1981; Noda 1985; Bussau 1992; Villora-Moreno 1998), consequently supporting the species status of $A$. abyssalis proposed by Bussau (1992).

In addition to confirming and re-interpreting the original observation (Pollock 1979), we recognize three overlooked characters: a paired globular body fringing the mouth (Fig. 1B), the leg IV sensory organs and the peduncles $(3 \mu \mathrm{m})$ that do not reach the claws (Fig. 1D). Each leg IV sensory organ consists of a spherical papilla and a short, apical spine (Fig. 1C). An enveloping cuticular sheath of the papilla was not evident, but may have been obscured due to the squeezed state of the specimen. The bad condition of the specimen also hindered our decisions on the presence/absence of the median cirrus, the secondary and tertiary clavae, legs II and III sensory organs, proximal pads of the internal digits and the seminal

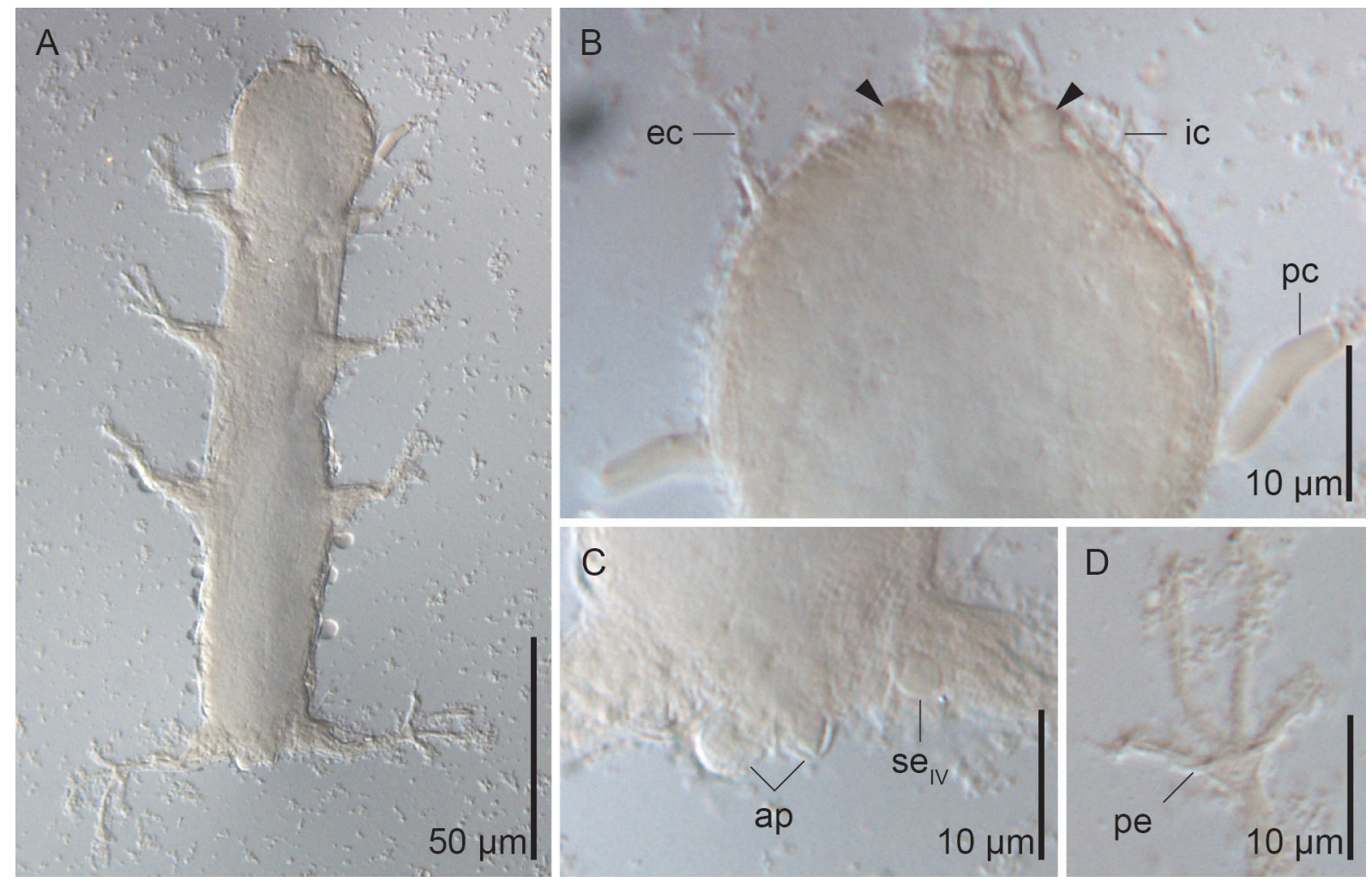

Fig. 1. Micrographs of Angursa bicuspis Pollock, 1979 (USNM W 50900). A. Habitus. B. Cephalic region with paired globular bodies (black arrowheads). C. Caudal region. D. Leg IV digits. 
receptacles. Additional collection of specimens from the type locality is necessary for more detailed discussion on this species morphology.

Angursa abyssalis Renaud-Mornant, 1981

Figs 2-3

\section{Emended diagnosis}

Angursa with club-shaped primary clavae longer than lateral cirri; pedestals of primary clavae and lateral cirri absent; flat, distorted-oval secondary clavae; flat, oval tertiary clavae slightly indented near external cirri; tapering cirri E with basal scapi; leg I sensory organs present; legs II and III sensory organs absent; leg IV sensory organs each as papilla enveloped in hemispherical cuticular sheath with short, apical spine; anal papillae absent.

\section{Material examined}

Holotype

ATLANTIC OCEAN - adult $P$; Southeast Atlantic, collected from off Angola; $2063 \mathrm{~m}$ deep site; $12^{\circ} 03^{\prime} 3 \mathrm{~S}, 12^{\circ} 20^{\prime} 5 \mathrm{E}$; Dinet leg.; MNHN AF05/77Ma.

\section{Additional specimens}

ATLANTIC OCEAN • 1 adult क; North Atlantic; $2205 \mathrm{~m}$ deep; Dinet \& Vivier leg.; MNHN AP345/560Ma.

MEDITERRANEAN SEA • 1 adult; Cassidaigne Canyon; 460 m deep; Vitiello \& Vivier leg.; MNHN AE120/78Ma.

\section{Remarks}

There were two primary purposes for the re-examination of this taxon. One purpose was to identify the secondary and tertiary clavae, which were not reported in the original description (Renaud-Mornant 1981). The second purpose was to accurately understand the morphology of the leg IV sensory organs, which was described as hemispherical papillae in the text, but drawn as elongate papillae in the figure of the original description (Renaud-Mornant 1981).

Unfortunately, the secondary and tertiary clavae were not recognised in the holotype, MNHN AF05/77Ma. However, they were evident in the additional specimen, MNHN AP345/560Ma. In this specimen, the paired secondary clavae were positioned in the dorsal area between the median cirrus and

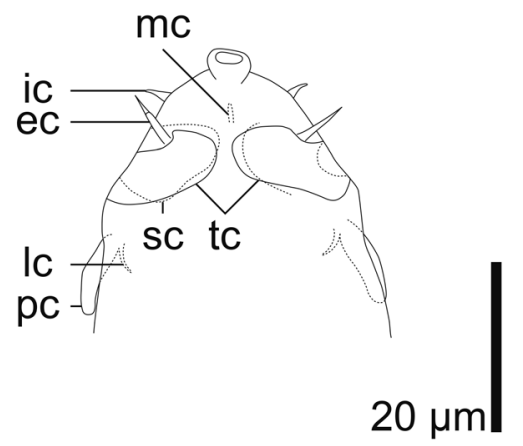

Fig. 2. Drawing of Angursa abyssalis Renaud-Mornant, 1981, cephalic region (ventral view) (USNM W 50900). 
the primary clavae and each was in the form of a flat, distorted-oval lobe (the complete contour was not recognisable) (Figs 2, 3A). The paired tertiary clavae were position ventrally, immediately posterior to the external cirri and each was in the form of a flat, transversally-elongated lobe with a slight indentation where the external cirrus arises (Figs 2, 3B). In the other additional specimen, MNHN AE120/78Ma, the secondary clavae were not recognised, but a paired structure indicative of clavae (tertiary clavae?) was observed in the latero-ventral position of the cephalic region (Fig. 3C). Further, a paired globular body fringing the mouth was recognised (Fig. 3D).

The leg IV sensory organs were recognised in all three specimens. The holotype and MNHNAP345/560Ma had leg IV sensory organs consisting of papillae enveloped in hemispherical cuticular sheaths with short, apical spines (Fig. 3E) similar to that described in the text of the original description (Renaud-Mornant 1981). On the other hand, the leg IV sensory organs of MNHN AE120/78Ma lacked the enveloping cuticular sheaths and the papillae appeared slightly elongate and also constricted at the base (Fig. 3F) as in fig. 1A of Renaud-Mornant (1981). Further, it is clear that fig. 1C of Renaud-Mornant (1981) is based on MNHN AE120/78Ma (Fig. 3F).
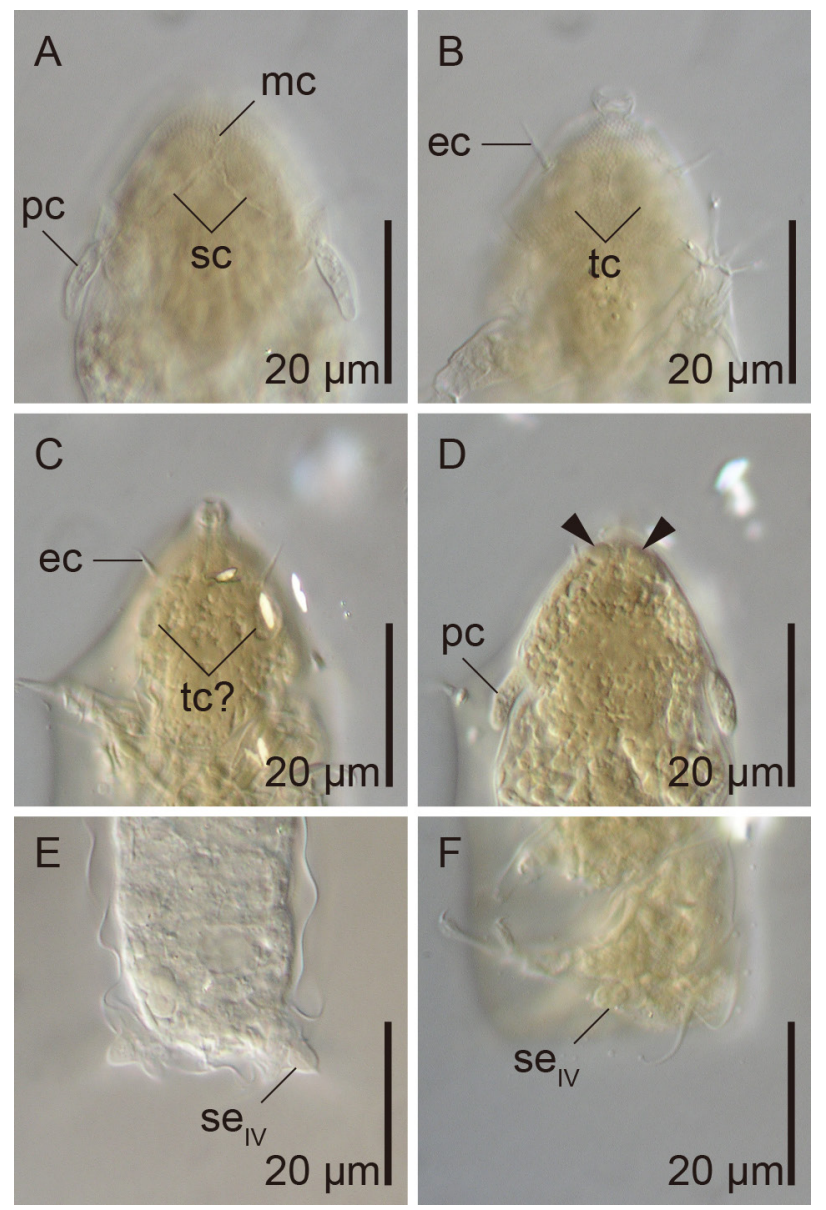

Fig. 3. Micrographs of specimens observed by Renaud-Mornant (1981) to describe Angursa abyssalis Renaud-Mornant, 1981 (A-B, E) and of Angursa sp. (C-D, F) by the present authors. A. Cephalic region (dorsal view) (MNHN AP345/560Ma). B. Cephalic region (ventral view) (MNHN AP345/560Ma). C. Cephalic region (ventral view) (MNHN AE120/78Ma). D. Cephalic region with paired globular bodies (black arrowhead) (MNHN AE120/78Ma). E. Leg IV sensory organs (MNHN AF05/77Ma). F. Leg IV sensory organ (MNHN AE120/78Ma). 
Other morphological characters of the three specimens confirm the original description (Renaud-Mornant 1981) except that a scapus was observed in one of the external cirri of the MNHNAP345/560Ma (Fig. 2). Here we provide measurements of the holotype missing in the original description: internal cirrus, $3 \mu \mathrm{m}$; external cirrus, $6 \mu \mathrm{m}$; primary clava, $10 \mu \mathrm{m}$; leg IV sensory organ, $5 \mu \mathrm{m}$ long and $3 \mu \mathrm{m}$ in diameter.

Our re-examination reveals that the term "balloon-shaped" used by Bussau (1992) and Villora-Moreno (1998) (probably based on the figure in the original description of Renaud-Mornant 1981) to describe the sensory organs of leg IV of $A$. abyssalis is inadequate since those of the holotype and MNHN AP345/560Ma had a hemispherical appearance. Further, we consider MNHN AE120/78Ma with "balloon-shaped" leg IV sensory organs (in the sense of Bussau 1992 and Villora-Moreno 1998) as an undescribed species. The difference in the morphology of the tertiary clavae also supports this view. However, MNHN AE120/78Ma is not in an acceptable condition for species description.

Based on the observation of the holotype and MNHN AP345/560Ma, Angursa abyssalis resembles A. clavifera and A. capsula by the club-shaped primary clavae longer than the lateral cirri, the leg IV sensory organs in hemispherical shape, and the lack of the anal papillae (Noda 1985; Bussau 1992). However, it differs from $A$. clavifera by the larger secondary clavae, the tertiary clavae slightly indented around the external cirri, and the absence of sensory organs on legs II and III (Noda 1985). It differs from A. capsula by the larger and closer situated pair of secondary clavae $(3 \mu \mathrm{m}$ apart in MNHN AP345/560Ma and $9 \mu \mathrm{m}$ apart in A. capsula measured from the drawing of a paratypic female in the original description see Bussau 1992), the tertiary clavae slightly indented around the external cirri (Bussau 1992) and a much shorter cirrus E (10 $\mu \mathrm{m}$ (body length, $141 \mu \mathrm{m})$ in A. abyssalis versus $19 \mu \mathrm{m}$ $(170 \mu \mathrm{m})$ in A. capsula).

Angursa lanceolata Renaud-Mornant, 1981

Fig. 4

\section{Emended diagnosis}

Angursa with bulbous primary clavae terminating in apices shorter than lateral cirri; pedestals of primary clavae and lateral cirri present; flat secondary clavae present; morphology of tertiary clavae unknown; lance-like cirri E; Leg I sensory organs present; legs II and III sensory organs absent; leg IV sensory organs each as elongate papilla with short apical spine; anal papillae absent.
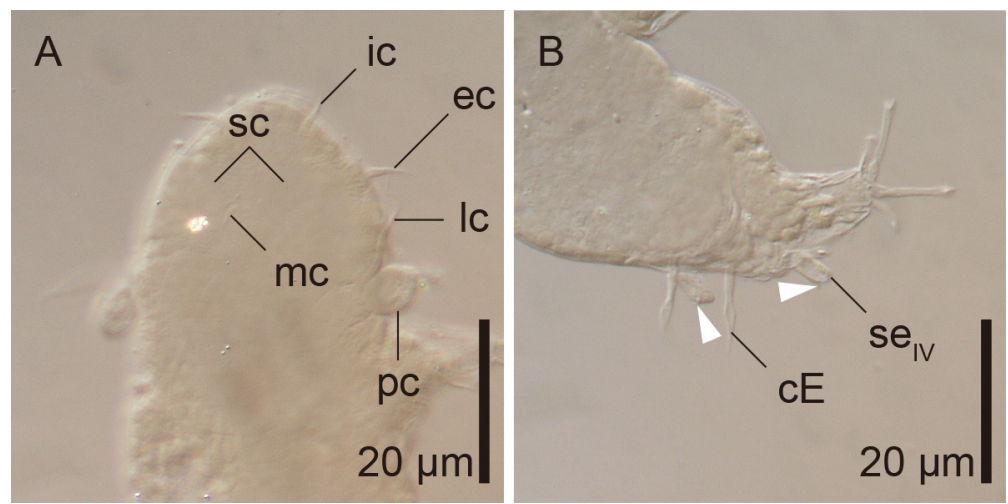

Fig. 4. Micrographs of Angursa lanceolata Renaud-Mornant, 1981 paratype. A. Cephalic region. B. Caudal region with leg IV sensory organ terminating in short, apical spine (white arrowheads). 


\author{
Material examined \\ Paratype \\ ATLANTIC OCEAN • 1 adult; mounted with the dried out holotype; Dinet leg.; AE128.
}

\title{
Remarks
}

The primary clavae were described as leaf-shaped by Renaud-Mornant (1981), but the primary clavae of the paratype we observed were bulbous papillae ( $8 \mu \mathrm{m}$ long, $6 \mu \mathrm{m}$ in diameter) with blunt apices (the apex were only recognised in one of the clavae) (Fig. 4A). Their neighbouring sensory organs, the lateral cirri $(17 \mu \mathrm{m})($ Fig. $4 \mathrm{~A})$, were apparently longer than reported in the original description $(11 \mu \mathrm{m})$ (Renaud-Mornant 1981). As it was drawn in the original description, the pedestals that support the primary clavae and the lateral cirri were apparent (Fig. 4A). We recognised the flat secondary clavae (Fig. 4A) which had already been mentioned as slightly hollow formations by Renaud-Mornant (1981), but their contours were difficult to observe. The presence and morphology of the tertiary clavae could not be revealed in this study. The characteristic cirri E (Fig. 4B) were confirmed, but their proportion seem slightly different that the drawing provided by Renaud-Mornant (1981). We recognised the short, apical spines of the leg IV sensory organs (Fig. 4B) which were overlooked in the original description (Renaud-Mornant 1981). Other measurements of the paratype are as follows: body length. $136 \mu \mathrm{m}$; median cirrus, $3 \mu \mathrm{m}$; internal cirrus, $6 \mu \mathrm{m}$; external cirrus, $6 \mu \mathrm{m}$; cirrus E, $11 \mu \mathrm{m}$; leg I sensory organ, $6 \mu \mathrm{m}$; leg IV sensory organ, $5 \mu \mathrm{m}$.

Angursa lanceolata closely resembles $A$. lingua by the bulbous primary clavae shorter than the lateral cirri, the apparent pedestals that support these two sensory organs, and the elongate leg IV sensory organs with apical spines (Renaud-Mornant 1981; Bussau 1992). However, these two species are easily distinguished from each other by the longer cephalic cirri and cirri E in A. lingua (median cirrus, $10 \mu \mathrm{m}$; internal cirrus, $9 \mu \mathrm{m}$; external cirrus $13 \mu \mathrm{m}$; lateral cirrus $28 \mu \mathrm{m}$; cirrus E, $20 \mu \mathrm{m}$ (body length, $145 \mu \mathrm{m}$ )) and by the lance-shaped cirri $\mathrm{E}$ in $A$. lanceolata versus tongue-shaped cirri $\mathrm{E}$ in $A$. lingua (RenaudMornant 1981; Bussau 1992).

Angursa capsula Bussau, 1992

Fig. 5

\section{Material examined}

All three specimens were collected from a manganese nodule area off Peru, but it is not clear whether the paratypes observed in this study were collected with the holotype or at a nearby site on a different day since the museum catalogue numbers were not mentioned in the original description (Bussau 1992).

\section{Holotype}

PACIFIC OCEAN • adult $O$; tropical SE Pacific, Peru Basin, collected from a manganese nodule area off Peru, 4140-4170 m deep; 0703'84" S, 88²8'15" W; 17 Feb. 1989; SMF 28.

\section{Paratypes}

PACIFIC OCEAN • 2 specimens collected from a manganese nodule area off Peru; SMF 29, SMF 30.

\section{Remarks}

The re-examination of the type material revealed the presence of the paired globular body fringing the mouth in the holotype (Fig. 5A), the shallow bases of the primary clavae and the lateral cirri which we do not regard as pedestals, and the morphology of the leg IV sensory organs (Fig. 5B) to be not significantly different from those of $A$. abyssalis and A. clavifera (Renaud-Mornant 1981; Noda 1985). The third point is especially important as its "capsule-shaped" leg IV sensory organ has been the primary 
diagnostic character for this species (Bussau 1992). The seconday and tertiary clavae were now very difficult to observe in the holotype. They were observed in SMF 29, but their complete contours were difficult to recognize.

\section{Material examined}

Angursa lingua Bussau, 1992

Out of the 19 specimens designated as type material (Bussau 1992), paratypes SMF 34, SMF 38, SMF 39 , SMF 42, and SMF 43 were observed. However, the mounting media were dried out in SMF 34, SMF 38, SMF 39 and SMF 42. Due to the same problem discussed for $A$. capsula, the collection locality of each specimen is not clear.

\section{Remarks}

No new information was obtained from the detailed observation of SMF 43.

\section{Emended diagnosis}

\section{Angursa antarctica Villora-Moreno, 1998}

Angursa with bulbous primary clavae shorter than lateral cirri; pedestals of primary clavae and lateral cirri absent; morphology of secondary clavae unknown; flat tertiary clavae around external cirri; tapering cirri E with annulated scapi situated on short cirrophores; leg I sensory organs present; legs II and III sensory organs absent; leg IV sensory organs each as papilla enveloped in hemispherical cuticular sheath with short, apical spine; weak anal papillae present.

\section{Remarks}

We amend the diagnosis of $A$. antarctica to include the information on the anal papillae noted in the original description (Villora-Moreno 1998) as well as the common pedestals of the primary clavae and
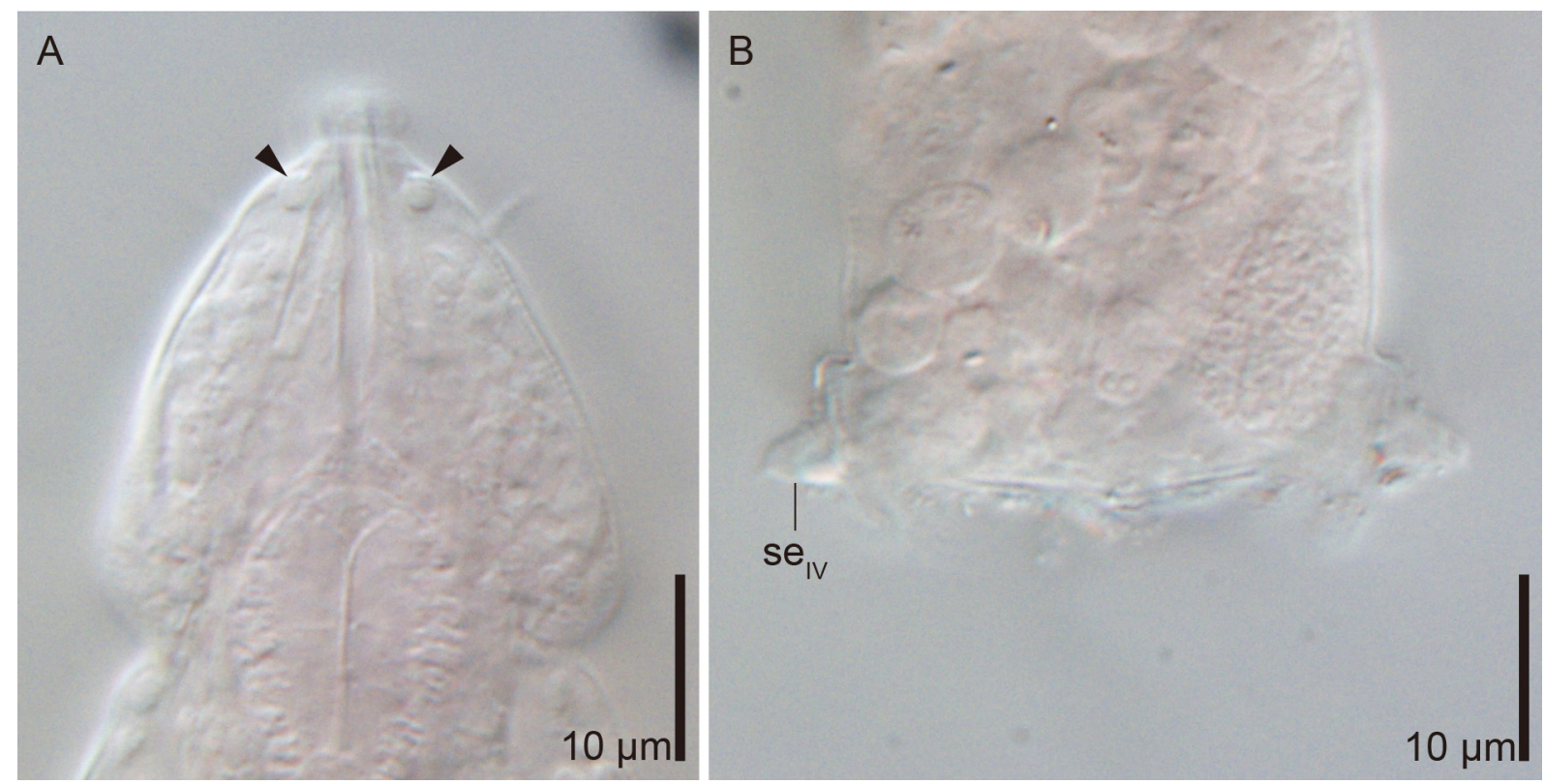

Fig. 5. Micrographs of Angursa capsula Bussau, 1992 (SMF 28). A. Cephalic region with paired globular bodies (black arrowheads). B. Caudal region. 
the lateral cirri that Villora-Moreno (1998) considered as a distinguishing character but did not include in the diagnosis of A. antarctica. Furthermore, Villora-Moreno (1998) reported the presence of the secondary clavae around the external cirri. As the external cirri are positioned ventrally, we believe that the clavae Villora-Moreno (1998) observed should be referred to as tertiary clavae which are always positioned ventrally in the genus.

\title{
Angursa seisuimaruae sp. nov. urn:lsid:zoobank.org:act:208985F1-BBB3-40B4-A2E4-26E8662277DD
}

Figs $6-7$

Angursa sp. - Kimura et al. 2018: table 23.

\section{Diagnosis}

Angursa with club-shaped primary clavae longer than lateral cirri; pedestals of primary clavae and lateral cirri absent; D-shaped secondary clavae; three-lobed tertiary clavae; leg I sensory organs as subdivided spines; legs II and III sensory organs absent; leg IV sensory organs each as papilla enveloped in hemispherical cuticular sheath with short, apical spine; anal papillae absent; seminal receptacles open latero-ventrally with short, sinuous ducts.

\section{Etymology}

The specific epithet refers to the T/V Seisuimaru of Mie University.

\section{Type material}

\section{Holotype}

PACIFIC OCEAN - adult 9 ; Northwestern Pacific, Japan, Sea of Kumano; between $33^{\circ} 59.5^{\prime} \mathrm{N}$, $136^{\circ} 56.7^{\prime} \mathrm{E}$ and $33^{\circ} 59.7^{\prime} \mathrm{N}, 136^{\circ} 56.7^{\prime} \mathrm{E}$; $768-796 \mathrm{~m}$ below sea level; 10 Nov. 2017; mounted in glycerol; Fujimoto leg.; KUZ Z2066.

\author{
Paratype \\ PACIFIC OCEAN • 1 adult +; same data as for holotype; KUZ Z2067.
}

\section{Type locality}

Sea of Kumano, Northwestern Pacific (between $33^{\circ} 59.5^{\prime} \mathrm{N}, 136^{\circ} 56.7^{\prime} \mathrm{E}$ and $33^{\circ} 59.7^{\prime} \mathrm{N}, 136^{\circ} 56.7^{\prime} \mathrm{E}$; depth range, 768-796 m) (Kimura et al. 2018).

\section{Description of holotype}

Adult female with unarmoured, slender body (143 $\mu \mathrm{m}$ long; $35 \mu \mathrm{m}$ wide between legs II and III) (Figs 6, 7A). Epicuticular pillars visible.

Cephalic region with unpaired median cirrus, paired internal cirri, paired external cirri, paired lateral cirri, paired primary clavae, paired secondary clavae, paired tertiary clavae, and mouth opening. Median cirrus $(1 \mu \mathrm{m})$ positioned dorsally. Internal cirri $(5 \mu \mathrm{m})$ inserted on anterior margin of body each consisting of scapus $(2 \mu \mathrm{m})$ and distal flagellar part with blunt tip $(2 \mu \mathrm{m})$. External cirri $(9 \mu \mathrm{m})$ inserted ventrally each consisting of scapus $(5 \mu \mathrm{m})$ and distal flagellar part with blunt tip $(5 \mu \mathrm{m})$. Lateral cirri $(4 \mu \mathrm{m})$ positioned dorso-laterally. Primary clavae $(10 \mu \mathrm{m})$ positioned immediately ventral to lateral cirri and both organs inserted directly on body with no apparent pedestal (only very slight rise). Primary clavae club-shaped and distal half slightly bent posteriorly. Secondary clavae (Figs 6, 7B) present posterior to median cirrus as flat, D-shaped structures without epicuticular pillars. Tertiary clavae (Figs 6, 7C) indented around external cirri, giving impression of three-lobed structures (one lobe directed anteriorly, 
interior to external cirri; second lobe developed interior to first lobe; third lobe developed posterior to external cirri) without epicuticular pillars. Anteriorly directed mouth at antero-most position of body. Buccal apparatus dissolved and only pharyngeal bulb recognised (length $14 \mu \mathrm{m}$, width $11 \mu \mathrm{m}$ ).

Paired cirri E $(18 \mu \mathrm{m})$ (Figs 6, 7D) as simple, tapering spines without recognisable annulation, inserted dorsally slightly anterior to leg IV.

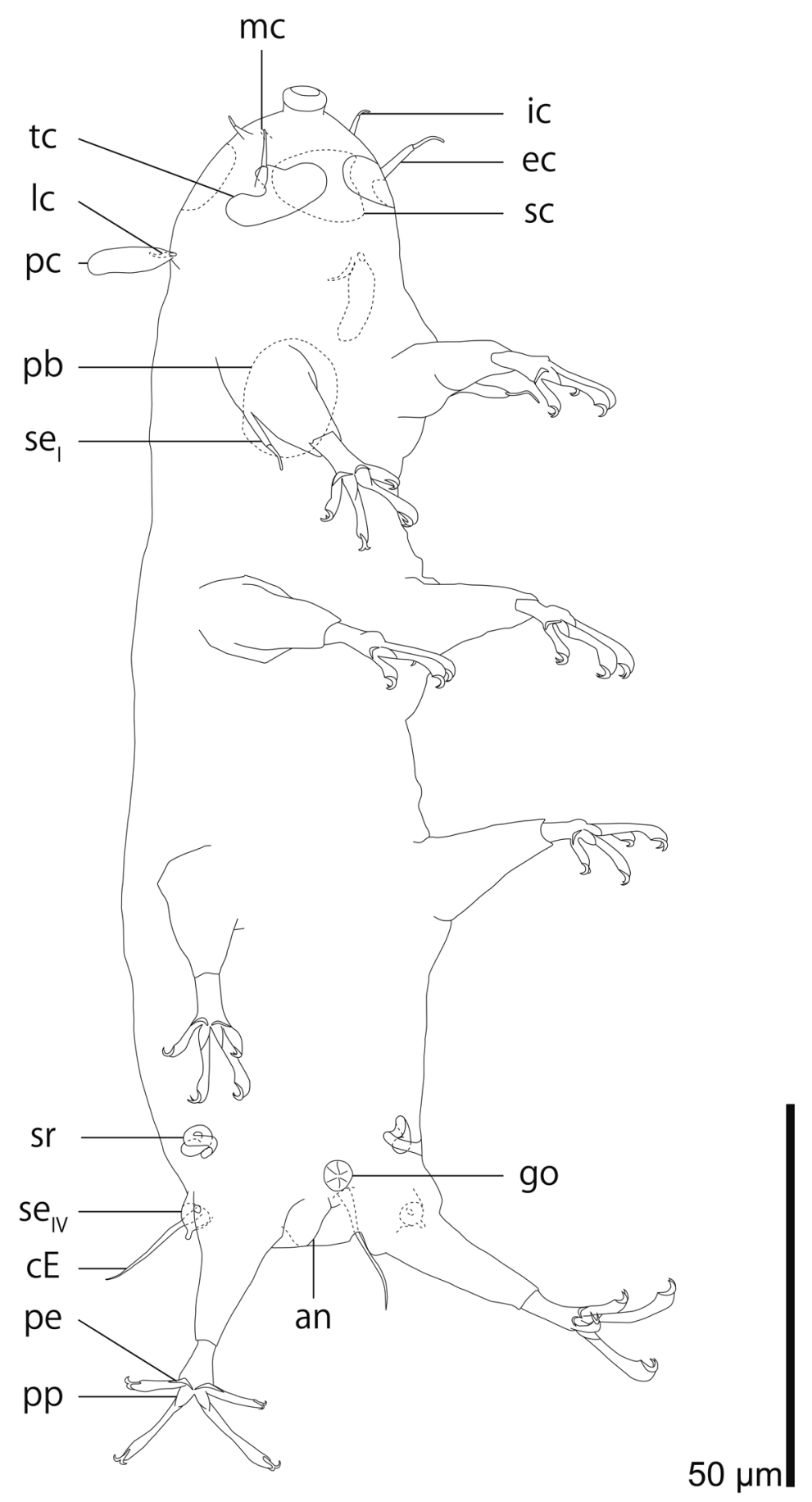

Fig. 6. Drawing of Angursa seisuimaruae sp. nov. (KUZ Z2066). 
Each leg consists of indistinct coxa, femur, indistinct tibia, and tarsus bearing four digits terminating in claws with two divergent points. Leg I sensory organ $(10 \mu \mathrm{m})$ (Figs 6, 7E) present on femur as spine consisting of proximal portion and distal portion with blunt tip. Legs II and III lack sensory organs. Leg IV sensory organs $(4 \mu \mathrm{m})$ (Figs 6, 7D) present at base of leg IV each as papilla enveloped in hemispherical cuticular sheath with short, apical spine. Internal digits have proximal pads and lack peduncles (Figs 6, 7E). External digits have arched peduncles at their base which never reach claws (Figs 6,7E). Internal digits always longer than external digits and leg IV has longer digits than those of legs I-III (leg I, internal digits $9 \mu \mathrm{m} /$ external digits $6 \mu \mathrm{m}$; leg II, 9/6; leg III, 10/6; leg IV, 13/7).

Rosette-like gonopore (4 $\mu \mathrm{m}$ in diameter) (Figs 6, 7F) situated $2 \mu \mathrm{m}$ anterior to anus. Longitudinal cuticluar fold of anus reach dorsal side (Figs 6, 7D). Paired seminal receptacles (Figs 6, 7F) positioned near latero-ventral margin of body, at level slightly anterior to gonopore. Each seminal receptacle duct runs interiorly, antero-dorsally, and then postero-ventrally terminating in round vesicle.
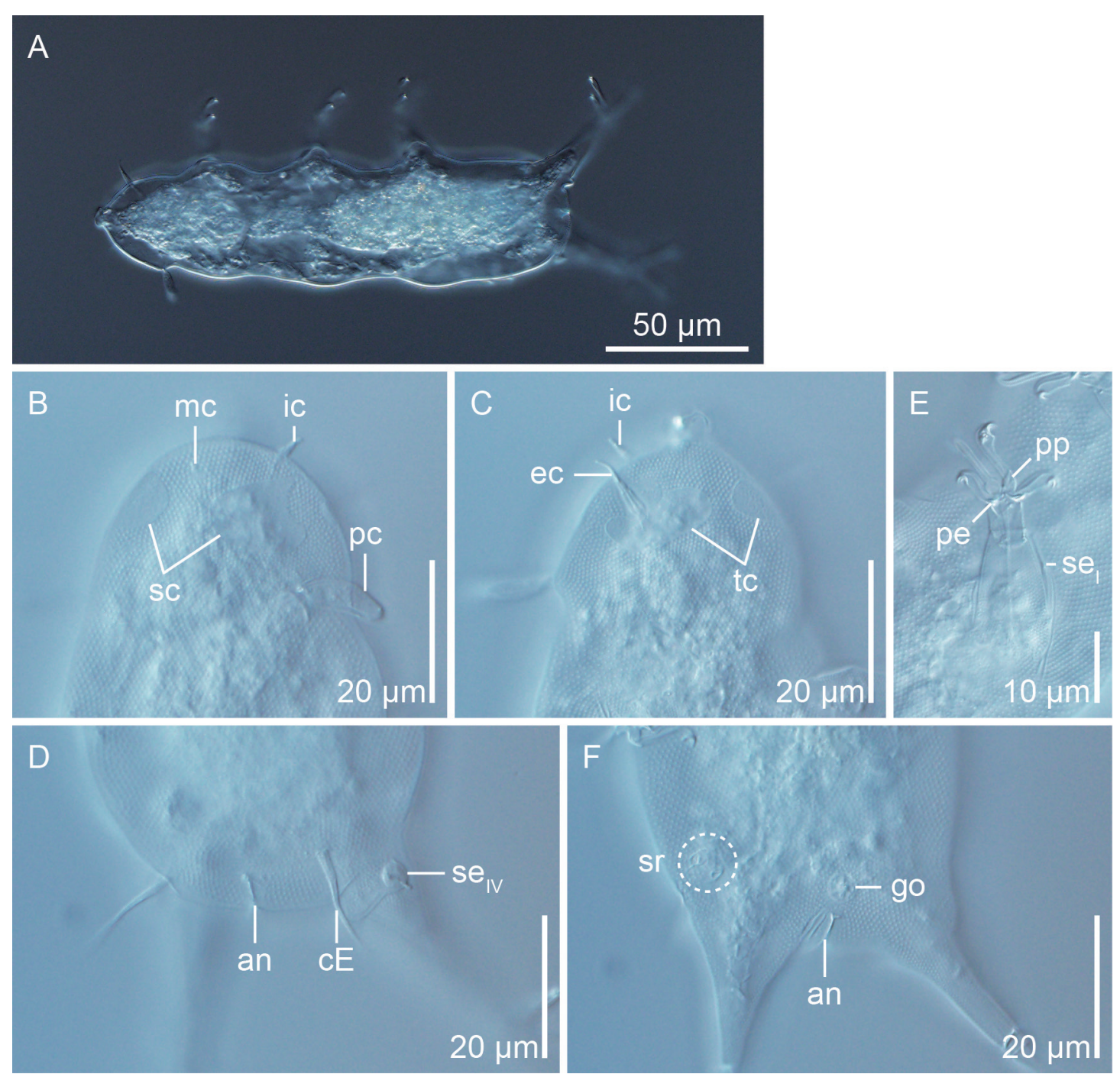

Fig. 7. Micrographs of Angursa seisuimaruae sp. nov. (KUZ Z2066). A. Habitus. B. Cephalic region (dorsal). C. Cephalic region (ventral). D. Caudal region (dorsal). E. Leg I. F. Caudal region (ventral). 


\section{Description of paratype}

Cephalic region accidentally destroyed during cleaning of specimen before observation and mouth opening, buccal apparatus, median cirrus, secondary clavae, and tertiary clavae not recognized. Primary clava $(11 \mu \mathrm{m})$ and scapi of internal, external, and lateral cirri recognized on torn cuticle. Presence of scapi suggests subdivision of lateral cirri as in the internal and external cirri. Gonopore and anus recognised before permanent preparation in lateral positioned body. Other characters confirm that of holotype (cirrus E, $17 \mu \mathrm{m}$; leg I sensory organ, $10 \mu \mathrm{m}$; leg IV sensory organ, $4 \mu \mathrm{m}$ ).

\section{Remarks}

Angursa seisuimaruae sp. nov. resembles A. abyssalis, A. clavifera, and A. capsula by the club-shaped primary clavae longer than the lateral cirri, the leg IV sensory organs in hemispherical shape, and the lack of the anal papillae (Renaud-Mornant 1981; Noda 1985; Bussau 1992). However, the new species is distinguished from all three species by its D-shaped secondary clavae and its three-lobed tertiary clavae (Noda 1985; Bussau 1992). Further, the new species's seminal receptacle ducts are shorter than A. clavifera's spiral ones (Noda 1985).

\section{Identification key to Angursa species}

1. Club-shaped primary clavae longer than lateral cirri 2 (A. bicuspis group)

- Bulbous primary clavae shorter than lateral cirri 6 (A. lanceolata group)

2. Well developed anal papillae A. bicuspis Pollock, 1979

- Anal papillae absent 3

3. Legs II and III sensory organs present; spiral seminal receptacle ducts A. clavifera Noda, 1985

- Leg II and III sensory organs absent. 4

4. Three-lobed tertiary clavae; D-shaped secondary clavae; seminal receptacles present

A. seisuimaruae sp. nov.

- Tertiary clavae with no indentation or only slightly indented around external cirri. 5

5. Secondary clavae situated close together (ca $3 \mu \mathrm{m})$; short $(10 \mu \mathrm{m})$ cirrus $\mathrm{E}$

A. abyssalis Renaud-Mornant, 1981

- Secondary clavae situated apart (ca $9 \mu \mathrm{m})$; long $(19 \mu \mathrm{m})$ cirrus E A. capsula Bussau, 1992

6. Leg IV sensory organs as papillae enveloped in hemispherical sheaths; cirri E with annulated scapi ...... A. antarctica Villora-Moreno, 1998

- Leg IV sensory organs as elongate papillae. 7

7. Cirri E lance-shaped A. lanceolata Renaud-Mornant, 1981

- Cirri E tongue-shaped A. lingua Bussau, 1992

\section{Discussion}

\section{Morphology}

Based on our re-examination of material used in the previous descriptions of species of Angursa, we warranted the species status of Angursa bicuspis and A. abyssalis, rejecting the proposal by VilloraMoreno (1998) to consider the former species as a senior synonym of the latter. Therefore, the genus Angursa has eight described species including the new species: A. abyssalis, A. antarctica, A. bicuspis (type species), A. capsula, A. clavifera, A. lanceolata, A. lingua, and A. seisuimaruae sp. nov. (see 
original description in Pollock 1979; Renaud-Mornant 1981; Noda 1985; Bussau 1992; Villora-Moreno 1998).

We confirm the emended diagnosis of Angursa by Bussau (1992) and recognize that all eight species have smooth, slender bodies with legs terminating in two internal digits with proximal pads and two external digits with peduncles, all four bearing claws with two divergent points (Renaud-Mornant 1981; Noda 1985; Bussau 1992; Villora-Moreno 1998) except for A. bicuspis with the proximal pads not reported in the original description (Pollock 1979) and not recognised in this study most probably due to the bad condition of the specimen (Fig. 1D). In addition to confirming the generic characters proposed by Bussau (1992), our new information on the secondary and tertiary clavae, seminal receptacles, and anal papillae discussed below were implemented in our amended generic diagnosis.

Previously, neither secondary nor tertiary clavae were reported in A. abyssalis, A. bicuspis, and A. lanceolata (Pollock 1979; Renaud-Mornant 1981) and the secondary clavae were not reported in A. antarctica (Villora-Moreno 1998; see also amended diagnosis provided in this study), but in this study, we recognised both clavae types in A. abyssalis (Figs 2, 3A-B) and the secondary clavae in A. lanceolata (Fig. 4A). Therefore A. abyssalis, A. capsula, A. clavifera, A. lingua and A. seisuimaruae sp. nov. (Noda 1985; Bussau 1992) have both clavae types, $A$. antarctica (tertiary clavae present) and A. lanceolata (secondary clavae present) have at least one of the types, whereas A. bicuspis is the only species with no report of the two clava types (Pollock 1979). Regarding this character distribution in the genus and our experience of the difficulty in observing these clavae after permanent preparation in A. seisuimaruae sp. nov. and the difficulty in re-observing them in A. capsula, we deem it likely that all Angursa species have both the secondary and tertiary clavae but overlooked in some species due to the condition of the specimen. Despite the difficulty in observation, the morphologies of these two clavae are useful to distinguish species and we recommend the description of their detailed morphologies (especially before permanent preparation in glycerol) when documenting species of Angursa.

The seminal receptacles of A. clavifera and A. seisuimaruae sp. nov. (Figs 6,7F) exhibit interspecific variation (Noda 1985). Although this character is not always easy to observe, we assume its presence in the other congeners (so far unknown) and have included the seminal receptacles in the generic diagnosis. In the future, we expect this character to play an important role in identification of Angursa species.

We recognize the two papillae reported by Pollock (1979) for A. bicuspis as a taxonomic valid character and called them the anal papillae (Fig. 1C). Other than A. bicuspis, A. antarctica has a weakly developed pair (Villora-Moreno 1998; see also amended diagnosis for this species). We consider this character and the terminally positioned anus known in all species (Pollock 1979; Renaud-Mornant 1981; Noda 1985; Bussau 1992; Villora-Moreno 1998) characteristics of Angursa and have incorporated them in the generic diagnosis.

In addition to new information on morphological characters we deem as characteristic of Angursa and significant for distinguishing species, we observed a pair of globular bodies fringing the mouth in A. bicuspis (Fig. 1B), Angursa sp. (Fig. 3D), A. capsula (Fig. 5A). Despite its easily-spotted state in these three species, it was not recognised in the well-preserved holotype of A. seisuimaruae sp. nov. We consider this structure as a potential character that may be useful for species identification but more observation of specimens are necessary to understand its nature, e.g., intra- and inter-specific variations and function (might be similar to the small sensory organ surrounding the mouth cone in Renaudarctus Kristensen \& Higgins, 1984; see Kristensen \& Higgins 1984; Hansen et al. 2012), and to utilise in taxonomy. Interspecific variation was stated for the size of the peduncles by Villora-Moreno (1998), but we did not recognize any significance in this character based on literature (Renaud-Mornant 1981; Noda 1985; Bussau 1992; Villora-Moreno 1998) and our observation. 
Our morphological comparison of species of Angursa also led us to recognize two morpho-groups in Angursa: the A. bicuspis group and the A. lanceolata group which might indicate two evolutionary lineages in the genus (implemented in the identification key). However, since these groups are detected solely on morphological data, molecular phylogenetic analyses are needed to test this hypothesis. The A. bicuspis group is comprised of A. abyssalis, A. bicuspis, A. capsula, A. clavifera, and A. seisuimaruae sp. nov. and shares the following character states: club-shaped primary clavae longer than lateral cirri with common pedestals weakly developed (Pollock 1979; Renaud-Mornant 1981; Noda 1985; Bussau 1992). The species of this group also have in common the simple, tapering cirri $\mathrm{E}$ and the leg IV sensory organs enveloped in hemispherical cuticular sheaths (the cuticular sheaths are not evident in A. bicuspis) (Pollock 1979; Renaud-Mornant 1981; Noda 1985; Bussau 1992). The A. lanceolata group is comprised of A. lanceolata, A. lingua, and A. antarctica and shares the following character states: bulbous primary clavae shorter than lateral cirri with apparent common pedestals (Renaud-Mornant 1981; Bussau 1992; Villora-Moreno 1998). Angursa lanceolata and A. lingua also have in common the cirri E with modified tips and the leg IV sensory organs as elongate papillae, in contrast to those of $A$. antarctica that resemble the A. bicuspis group (Renaud-Mornant 1981; Bussau 1992; Villora-Moreno 1998).

\section{Biogeography}

As a consequence of our re-examination including the reinstatement of $A$. abyssalis, the distribution records of both A. bicuspis and A. abyssalis need to be updated.

As revealed in the present study, the original diagnosis of $A$. bicuspis constitutes a combination of two different species. Therefore, only the holotype should be regarded as a valid record of A. bicuspis and the additional specimen from a $400 \mathrm{~m}$ deep site off the coast of North Carolina, USA as an unidentified species. All subsequent records of A. bicuspis (D'Addabbo Gallo et al. 1987; Grimaldi de Zio \& D'Addabbo Gallo 1987; Accogli et al. 2011) are presumed records of A. b. abyssalis inferred from subsequent studies (De Zio Grimaldi \& Gallo D'Addabbo 2001; Gallo D'Addabbo et al. 2001; De Zio Grimaldi et al. 2003) and from context (Accogli et al. 2011) and they will be discussed in the next paragraph.

Regarding A. abyssalis (reported as A. b. abyssalis), our re-examination of the three specimens from Renaud-Mornant (1981) revealed that only the holotype from a $2063 \mathrm{~m}$ deep site off Angola (MNHN AF05/77Ma) and the specimen from a $2205 \mathrm{~m}$ deep site in the North Atlantic (MNHN AP345/560Ma) are acceptable as A. abyssalis and that specimen from a $460 \mathrm{~m}$ deep site in the Mediterranean (MNHN AE120/78Ma) is an undescribed species. This was based on the change in the diagnostic morphology of the leg IV sensory organs. Confirmation of this morphology for all records is crucial for confidently identifying the re-diagnosed $A$. abyssalis. Unfortunately, no record after Renaud-Mornant (1981) mentioned the morphological detail of their "A. b. abyssalis" or "A. bicuspis" specimens (D'Addabbo Gallo et al. 1987; Grimaldi de Zio \& D’Addabbo Gallo 1987; Sandulli et al. 1999; De Zio Grimaldi \& Gallo D'Addabbo 2001; Gallo D'Addabbo et al. 2001; De Zio Grimaldi et al. 2003; Accogli et al. 2011; Romano et al. 2011) and we suggest these records as reports of unidentified species. Further, these reports are from two distant geographical regions, the Mediterranean (D'Addabbo Gallo et al. 1987; Grimaldi de Zio \& D'Addabbo Gallo 1987; Sandulli et al. 1999; De Zio Grimaldi \& Gallo D’Addabbo 2001; Gallo D'Addabbo et al. 2001; De Zio Grimaldi et al. 2003; Accogli et al. 2011) and the Gulf of Mexico (Romano et al. 2011), and we should consider the possibility of these records to include more than one species. It is also noteworthy that De Zio Grimaldi et al. (2003) notes "A. b. abyssalis" from Amendolara Shoal (D’Addabbo Gallo et al. 1987; Grimaldi de Zio \& D’Addabbo Gallo 1987) is like A. bicuspis which might suggest multiple species from the Mediterranean including MNHN AE120/78Ma of Renaud-Mornant (1981). 
A summary of the records with our new interpretation of A. abyssalis and A. bicuspis is provided as Fig. 8 .

Other species of Angursa, A. antarctica, A. capsula, A. lanceolata, and A. seisuimaruae sp. nov. are known only near their type localities and their distributions do not cross any known dispersal barrier (Renaud-Mornant 1981; Bussau 1992; Villora-Moreno 1998). However, A. clavifera and A. lingua are also known from localities distant from their type localities (Noda 1985, 1994; Bussau 1992; Da Rocha et al. 2013; Okanishi et al. 2016). Angursa clavifera is known from a beach in the Ryukyu Islands (Noda 1994) far apart from other beaches in the Japanese Islands (type locality) (Noda 1985). Although the Japanese and Ryukyu Islands are both under the influence of a warm current, Kuroshio, they are known to harbour different species in some marine invertebrate genera (e.g., tideland snails: Kojima et al. 2003; limpets: Nakayama et al. 2017) and we consider this as a potential dispersal barrier for marine tardigrades, especially for those that favor the intertidal zone. Therefore, we think that the record of this species from the Ryukyu Islands (Noda 1994) is dubious. Considering the possibility of cryptic speciation, we would need molecular data in combination with detailed morphological examination

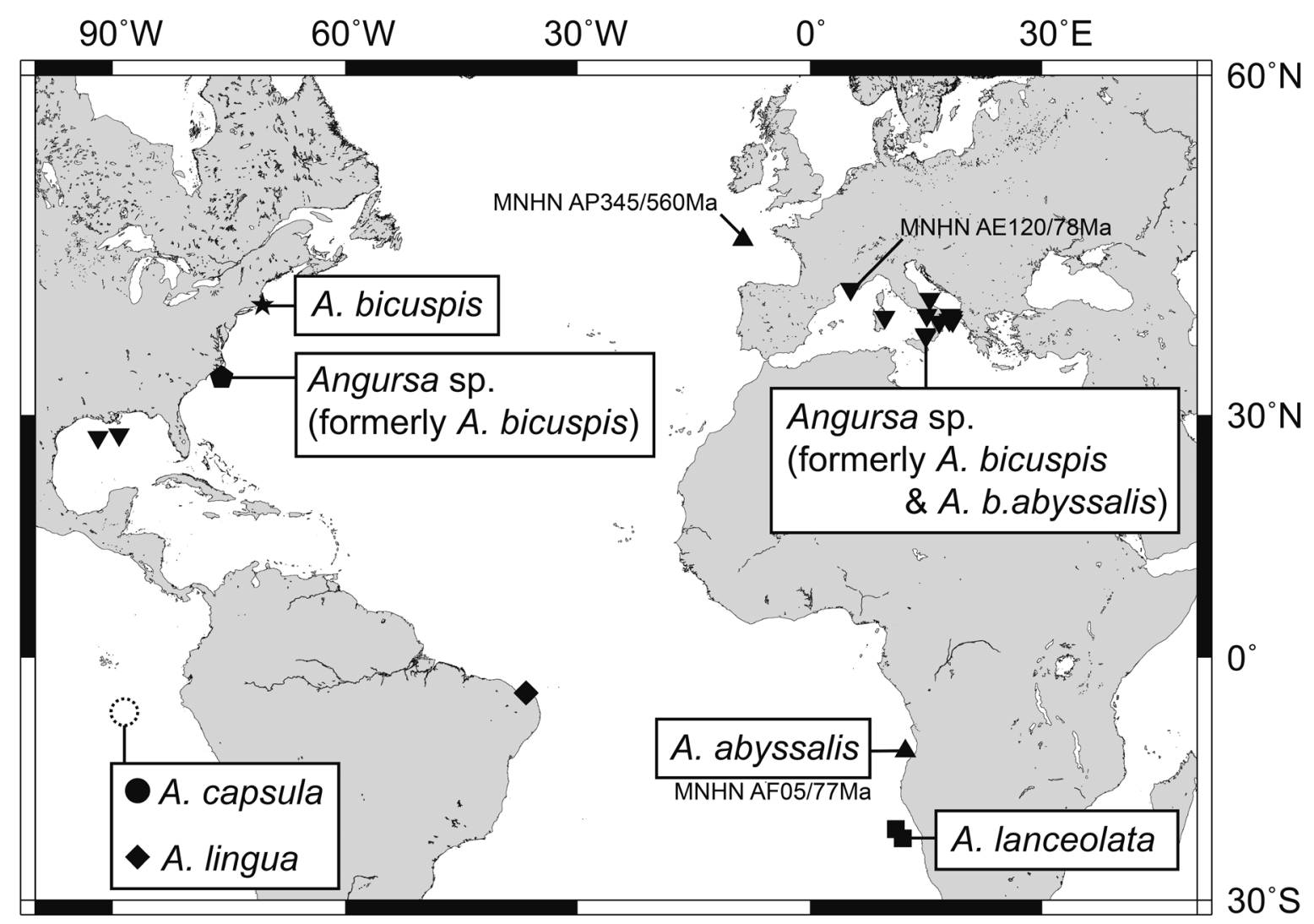

Fig. 8. Records of Angursa abyssalis Renaud-Mornant, 1981, A. bicuspis Pollock, 1979, and some other species. Three specimens originally identified as A. b. abyssalis (Renaud-Mornant 1981) are labelled with their museum catalogue number. Localities are based on the following literature summarized in Kaczmarek et al. (2015): Pollock (1979); Renaud-Mornant (1981); D’Addabbo Gallo et al. (1987); Grimaldi de Zio \& D’Addabbo Gallo (1987); Bussau (1992); Sandulli et al. (1999); De Zio Grimaldi \& Gallo D'Addabbo (2001); Gallo D'Addabbo et al. (2001); De Zio Grimaldi et al. (2003); Accogli et al. (2011), and Romano et al. (2011). The map was originally generated with GMT ver. 5.1.1 (Wessel et al. 2013). 
to verify this hypothesis. Another record of this species is from a $175-177 \mathrm{~m}$ deep site off the coast of the type locality (Okanishi et al. 2016). According to the morphology reported (Okanishi et al. 2016), the specimen definitely belongs to the A. bicuspis group, but there is no positive evidence to support its species identity as $A$. clavifera and we regard this report as a record of an unidentified species. The reports of A. lingua from the Brazilian continental shelf (20 m and $100 \mathrm{~m}$ deep) (Da Rocha et al. 2013) has been suspected by Kaczmarek et al. (2015) since the species was originally described from Peruvian abyssal depths (4140-4170 m) (Bussau 1992). In addition to this ecological perspective, we would like to note that the two localities (Bussau 1992; Da Rocha et al. 2013) are intervened by the Panama Isthmus. This geological barrier is already known to restrict the gene flow of meiofauna (nemertean genus Ototyphlonemertes Diesing, 1863: Leasi et al. 2016) and we reckon the two populations have undergone cryptic speciation.

To improve our scanty knowledge of the biogeographical pattern of Angursa, we first need to accumulate reports with high standard identification, documenting as many characters as possible, especially the secondary and tertiary clavae and seminal receptacles which have received limited attention despite being crucial to the validity of species identification. At the same time, the use of molecular markers (at least the mitochondrial cytochrome oxidase subunit I) is inevitable to detect cryptic speciation and to understand the phylogenetic history of these animals in the geographic context.

\section{Acknowledgements}

The National Museum of Natural History of the Smithsonian Institute is thanked for the loan of the type material of A. bicuspis. The Senckenberg Natural History Museum, Frankfurt/Main, Germany is thanked for the loan of the type material of A. lingua and A. capsula. The authors also greatly appreciated the generous support from Tarek Meziane and Cédric Hubas, the Museum national d'Histoire naturelle, Paris, France who provided the type material of A. abyssalis and A. lanceolata. The captain and crew of the T/V Seisuimaru of Mie University, Taeko Kimura of Mie University, and the scientists of the research cruise No. 1722 are warmly thanked for their assistance in collecting $A$. seisuimaruae sp. nov. This work was funded by the Carlsberg Foundation (grant no. 2012010127 and CF15-0189) and the European Commission's (FP6) Integrated Infrastructure Initiative Programme, SYNTHESYS to FRTAF 2836 to JGH.

\section{References}

Accogli G., Gallo M., D’Addabbo R. \& Hansen J.G. 2011. Diversity and ecology of the marine tardigrades along the Apulian Coast. Journal of Zoological Systematics and Evolutionary Research 49 (Suppl. 1): 53-57. https://doi.org/10.1111/j.1439-0469.2010.00598.x

Bussau C. 1992. New deep-sea Tardigrada (Arthrotardigrada, Halechiniscidae) from manganese nodule area of the eastern South Pacific. Zoologica Scripta 21: 79-91.

https://doi.org/10.1111/j.1463-6409.1992.tb00311.x

Da Rocha C.M.C., Dos Santos E.C.L., Gomes E.L.Jr, da Rocha Moura J., Santana e Silva L.G. \& Barbosa D.F. 2013. New records of marine tardigrades from Brazil. Journal of Limnology 72 (S1): 102-107. https://doi.org/10.4081/jlimnol.2013.s1.e12

D’Addabbo Gallo M., Morone de Lucia M.R. \& Grimaldi de Zio S. 1987. Heterotardigrada of the Amendolara Shoal, High Ionian Sea. In: Bertolani R. (ed.) Biology of Tardigrades. Selected Symposia and Monographs U.Z I., 1: 93-101. Mucchi, Modena, Italy.

De Zio Grimaldi S. \& Gallo D'Addabbo M. 2001. Further data on the Mediterranean Sea tardigrade fauna. Zoologischer Anzeiger 240: 345-360. https://doi.org/10.1078/0044-5231-00042 
De Zio Grimaldi S., Gallo D’Addabbo M., Sandulli R. \& D'Addabbo R. 2003. Checklist of the Italian marine Tardigrada. Meiofauna Marina 12: 97-135.

Fujimoto S., Jørgensen A. \& Hansen J.G. 2017. A molecular approach to arthrotardigrade phylogeny (Heterotardigrada, Tardigrada). Zoologica Scripta 46: 496-505. https://doi.org/10.1111/zsc.12221

Gallo D’Addabbo M., De Zio Grimaldi S. \& Sandulli R. 2001. Heterotardigrada of two submarine caves in S. Domino Island (Tremiti Islands) in the Mediterranean Sea with the description of two species of Stygarctidae. Zoologischer Anzeiger 240: 361-369. https://doi.org/10.1078/0044-5231-00043

Giere O. 2009. Meiobenthology: The Microscopic Motile Fauna of Aquatic Sediments. Springer-Verlag, Berlin/Heidelberg. https://doi.org/10.1007/978-3-540-68661-3

Grimaldi de Zio S. \& D’Addabbo Gallo M. 1987. Archechiniscus minutus n. sp. and its systematic position within Arthrotardigrada (Tardigrada: Heterotardigrada). In: Bertolani R. (ed.), Biology of Tardigrades. Selected Symposia and Monographs U.Z.I., 1: 253-260. Mucchi, Modena, Italy.

Hansen J.G., Kristensen R.M. \& Jørgensen A. 2012. The armoured marine tardigrades (Arthrotardigrada, Tardigrada). The Royal Danish Academy of Sciences and Letters. Scientia Danica, Series B, Biologica 2: $1-91$.

Kaczmarek Ł., Bartels P.J., Roszkowska M. \& Nelson D.R. 2015. The zoogeography of marine tardigrades. Zootaxa 4037: 1-189. https://doi.org/10.11646/zootaxa.4037.1.1

Kimura T., Kimura S., Jimi N., Kakui K., Tomioka S., Oya Y., Matsumoto Y., Tanabe Y., Hasegawa N., Hookabe N., Homma R., Hosoda Y., Fujimoto S., Kuramochi T., Fujita T., Ogawa A., Kobayashi I., Ishida Y., Tanaka H., Onishi H., Shimetsugu M., Yoshikawa A., Tanaka M., Kushida Y., Maekawa Y., Nakamura T., Okumura J. \& Tanaka K. 2018. Benthic deep-sea fauna in the Sea of Kumano, Mie Prefecture, Japan. Annals of Field Research and Technology Mie University 16: 1-32. [In Japanese.]

Kojima S., Kamimura S., Kimura T., Hayashi I., Iijima A. \& Furota T. 2003. Phylogenetic relationships between the tideland snails Batillaria flectosiphonata in the Ryukyu Islands and B. multiformis in the Japanese Islands. Zoological Science 20: 1423-1433. https://doi.org/10.2108/zsj.20.1423

Kristensen R.M. 1983. Loricifera, a new phylum with Aschelminthes characters from the meiobenthos. Zeitschrift für Zoologische Systematik und Evolutionsforschung 21: 163-180.

https://doi.org/10.1111/j.1439-0469.1983.tb00285.x

Kristensen R.M. \& Higgins R.P. 1984. A new family of Arthrotardigrada (Tardigrada: Heterotardigrada) from the Atlantic coast of Florida, U.S.A. Transactions of the American Microscopical Society 103: 295-311. https://doi.org/10.2307/3226191

Leasi F., Da Silva Andrade S.C. \& Norenburg J.L. 2016. At least some meiofaunal species are not everywhere. Indication of geographic, ecological and geological barriers affecting the dispersion of species of Ototyphlonemertes (Nemertea, Hoplonemertea). Molecular Ecology 25: 1381-1397. https://doi.org/10.1111/mec.13568

Nakayama R., Sasaki T. \& Nakano T. 2017. Molecular analysis reveals a new cryptic species in a limpet Lottia kogamogai (Patellogastropoda: Lottiidae) from Japan. Zootaxa 4277 (2): 237-251.

https://doi.org/10.11646/zootaxa.4277.2.4

Noda H. 1985. Description of a new subspecies of Angursa bicuspis Pollock (Heterotardigrada, Halechiniscidae) from Tanabe Bay, Japan. Publications of the Seto Marine Biological Laboratory 30: 269-276. Available from https://hdl.handle.net/2433/176110 [accessed 4 Feb. 2019].

Noda H. 1994. [Tardigrades from sand beaches in Okinawa.] Proceedings of the Japanese Society of Systematic Zoology 51: 79. [In Japanese.] (Published abstract) https://doi.org/10.19004/pjssz.51.0_79_1 
Okanishi M., Sentoku A., Fujimoto S., Jimi N., Nakayama R., Yamana Y., Yamauchi H., Tanaka H., Kato T., Kashio S., Uyeno D., Yamamoto K., Miyazaki K. \& Asakura A. 2016. Marine benthic community in Shirahama, southwestern Kii Peninsula, central Japan. Publications of the Seto Marine Biological Laboratory 44: 7-52. Available from https://hdl.handle.net/2433/217458 [accessed 4 Feb. 2019].

Pollock L.W. 1979. Angursa bicuspis n. g., n. sp., a new marine arthrotardigrade from the western North Atlantic. Transactions of the American Microscopical Society 98: 558-562.

https://doi.org/10.2307/3225907

Renaud-Mornant J. 1981. Deux nouveaux Angursa Pollock, 1979, du domaine abyssal (Tardigrada, Arthrotardigrada). Tethys 10: 161-164.

Romano F. III, Gallo M., D’Addabbo R., Accogli G., Baguley J. \& Montagna P. 2011. Deep-sea tardigrades in the northern Gulf of Mexico with a description of a new species of Coronarctidae (Tardigrada: Arthrotardigrada), Coronarctus mexicus. Journal of Zoological Systematics and Evolutionary Research 49 (S1): 48-52. https://doi.org/10.1111/j.1439-0469.2010.00597.x

Sáiz-Salinas J.I., Ramos A., García R.J., Troncoso J.S., San Martin G., Sanz C. \& Palacin C. 1997. Quantitative analysis of macrobenthic soft-bottom assemblages in South Shetland waters (Antarctica). Polar Biology 17: 393-400. https://doi.org/10.1007/PL00013382

Sandulli R., Gallo D’Addabbo M., De Lucia Morone M.R., D’Addabbo R., Pietanza R. \& De Zio Grimaldi S. 1999. Preliminary investigations on meiofauna of two caves in San Domino Island (Tremiti Archipelago). Biologia Marina Mediterranea 6: 437-440.

Villora-Moreno S. 1998. Deep-sea Tardigrada from South Shetland Islands (Antarctica) with description of Angursa antarctica sp. nov. (Arthrotardigrada, Halechiniscidae). Polar Biology 19: 336-341. https://doi.org/10.1007/s003000050255

Wessel P., Smith W.H.F., Scharroo R., Luis J. \& Wobbe F. 2013. Generic mapping tools: improved version released. Eos, Transactions of the American Geophysical Union 94 (45): 409-10. https://doi.org/10.1002/2013EO450001

Manuscript received: 13 November 2018

Manuscript accepted: 21 January 2019

Published on: 28 March 2019

Topic editor: Rudy Jocqué

Desk editor: Marianne Salaün

Printed versions of all papers are also deposited in the libraries of the institutes that are members of the EJT consortium: Muséum national d'Histoire naturelle, Paris, France; Botanic Garden Meise, Belgium; Royal Museum for Central Africa, Tervuren, Belgium; Royal Belgian Institute of Natural Sciences, Brussels, Belgium; Natural History Museum of Denmark, Copenhagen, Denmark; Naturalis Biodiversity Center, Leiden, the Netherlands; Museo Nacional de Ciencias Naturales-CSIC, Madrid, Spain; Real Jardín Botánico de Madrid CSIC, Spain; Zoological Research Museum Alexander Koenig, Bonn, Germany. 